\title{
A canalis mandibulae lefutásának vizsgálata különböző vertikális arctípusokban
}

\author{
Mártha I. Krisztina dr. ${ }^{1}$ - Cristina Bica ${ }^{2}$ \\ Kész Blanka oh. ${ }^{3}$. Kerekes Máthé Bernadette dr. ${ }^{4}$
}

\begin{abstract}
${ }^{1}$ Marosvásárhelyi Orvosi és Gyógyszerészeti Egyetem, Fogorvosi Kar, ${ }^{1}$ Fogszabályozás Tanszék, Marosvásárhely ${ }^{2}$ Marosvásárhelyi Orvosi és Gyógyszerészeti Egyetem, Fogorvosi Kar, Gyerekfogászati Tanszék, Marosvásárhely ${ }^{3}$ Marosvásárhelyi Orvosi és Gyógyszerészeti Egyetem, Fogorvosi Kar, Marosvásárhely

${ }^{4}$ Marosvásárhelyi Orvosi és Gyógyszerészeti Egyetem, Fogorvosi Kar, Fogmorfológia és Anyagtan Tanszék, Marosvásárhely
\end{abstract}

Bevezetés: A canalis mandibulae és a foramen mandibulae helyzetének pontos ismerete az alsó állcsonton végzett sebészeti és endodontiás beavatkozások esetén rendkívül fontos.

Célkitüzés: Ezen anatómiai képletek helyzetének vizsgálata különböző vertikális arctípusokban.

Módszer: 26 normodivergens, 26 hipodivergens és 28 hiperdivergens arctípussal rendelkező egyén panoráma-röntgenfelvételén (összesen 1360 mérés) mértük az interdentalis septumok, oldalsó fogak gyökércsúcsai, mandibulatest alapja, állkapocsszöglet és a canalis mandibularis közötti távolságot, a csatorna lefutását, illetve a foramen mandibulae és a felszálló szár elülső és hátsó széle közötti távolságokat.

Eredmények: ANOVA- és t-teszt statisztikai elemzéssel rámutattunk arra, hogy a felszálló ág hátsó széléhez a foramen mandibulae távolabb helyezkedett el hipodivergens arctípusnál, a hiperdivergens arctípusnál a canalis mandibulae közelebb helyezkedett a gyökércsúcsokhoz, hipodivergens típusoknál pedig a mandibulatest alapjához. Normo- és hiperdivergens egyéneknél a csatorna lefutása meredekebb és lefutásában egyre inkább eltávolodik a mandibula alapjához húzott érintőtool.

Következtetés: A canalis mandibulae lefutása, valamint a foramen mandibulae helyzete szignifikáns eltéréseket mutatott a különböző vertikális arctípusok esetében.

Orv Hetil. 2017; 158(46): 1841-1847.

Kulcsszavak: canalis mandibulae, foramen mandibulae, vertikális arctípus, panoráma-röntgenfelvétel

\section{Study of the canalis mandibulae morphology in different vertical facial types}

Introduction: The precise knowledge of the position of canalis mandibulae and foramen mandibulae is important for surgical and endodontic interventions on the mandible.

Aim: The aim of the study is to examine the position of these anatomical landmarks in different vertical facial types. Method: In the panorama radiograph of 26 normodivergent, 26 hypodivergent and 28 hyperdivergent arthritis (total of 1360 measurements) we measured the distance between the canalis mandibulae and interdental septums, the apex of the lateral teeth, the mandibular base, the goniac angle, and the steepness of the canal and the distance the foramen mandibulae to the anterior and posterior margin of the ramus.

Results: ANOVA and t-test statistical analysis showed that the foramen mandibulae is farer from the posterior margin of the ramus in hipodivergent facial types, in hyperdivergent facial types the canalis mandibulae was closer to the root apex of posterior teeth and in hypodivergent types to the base of the mandible. In normal and hyperdivergent individuals, the canalis mandibulae runs steeper and in the course of running it is increasingly distanced from the tangent to the base of the mandible.

Conclusion: The position of the canalis mandibulae and the foramen mandibulae showed significant differences in the different vertical facial types.

Keywords: canalis mandibulae, foramen mandibulae, vertical facial types, panoramic x-ray

Mártha IK, Bica C, Kész B, Kerekes Máthé B. [Study of the canalis mandibulae morphology in different vertical facial types]. Orv Hetil. 2017; 158(46): 1841-1847.

(Beérkezett: 2017. július 29.; elfogadva: 2017. augusztus 23.) 


\section{Rövidítések}

$\mathrm{CM}=$ canalis mandibulae; $\mathrm{FM}=$ foramen mandibulae; $\mathrm{Go}=$ állkapocsszög, Mld = első nagyőrlő distalis gyökere; $\mathrm{Mlm}=$ első nagyőrlő mesialis gyökere; M2d = második nagyőrlő distalis gyökere; $\mathrm{M} 2 \mathrm{~m}$ = második nagyőrlő mesialis gyökere; $\mathrm{RA}$ = ramus mandibulae anterior széle; $\mathrm{RP}=$ ramus mandibulae posterior széle

A canalis mandibularis (CM) a nervus alveolaris inferiort, valamint az arteria és vena alveolaris inferiort tartalmazó csatorna, amely az állkapocs felszálló ágán, valamint testén halad át. Fogászati szempontból rendkívüli figyelmet kell fordítani lefutására, hiszen sok beavatkozás (orthognathsebészet, implantáció, gyökérkezelés, bölcsességfog-eltávolítás, érzéstelenítés) során fennáll a csatorna sérülésének veszélye, amelynek következményeként sérülhet a csatornában futó ér-ideg köteg bármely eleme, hosszan tartó érzéskiesést vagy nehezen csillapítható vérzést okozva $[1,2]$. A foramen mandibulae (FM) helyzetének pontos ismerete a sikeres helyi érzéstelenítés érdekében elengedhetetlen [3]. A CM és az impaktált alsó bölcsességfog csúcsa közötti távolság ismerete növeli a beavatkozás rizikóbecslésének fontosságát [4].

Több tanulmány is foglalkozik a csatorna lefutását befolyásoló tényezőkkel, többek közt ilyennek bizonyult a nem, kor, földrajzi elhelyezkedés vagy az állkapocsszög mérete $[5,6]$.

Az állcsontok növekedési iránya befolyásoló tényezőként hat az arc morfológiájára, a különböző anatómiai képletek méretére és alakjára. Az arc vertikális növekedési és fejlődési iránya hatással van olyan képletek helyzetére, amelyek befolyásolhatják a CM, illetve az FM helyzetét $[7,8]$, a felszálló ág és az állkapocsszöglet méretét [9].

A fej pozíciójának helyes beállításával a panorámaröntgenfelvételen megbízható mérések végezhetők az állkapocs hátsó területén [10]. Kettős lefutás esetén a panoráma-röntgenfelvétel nem elegendő, anatómiai vizsgálatok igazolták a makroszkopikus vizsgálatok nagyobb értékét [11].

Jelen tanulmány célkitűzése megállapítani azt, hogy a különböző vertikális arctípusokban változik-e a CM, valamint az FM helyzete és lefutása.

\section{Anyag és módszer}

Tanulmányunkban 80 egyén panoráma-röntgenfelvételét értékeltünk ki (54 lány, 26 fiú, átlagéletkor 14,3 + 1,8 év). Az esetek a Marosvásárhelyi Orvosi és Gyógyszerészeti Egyetem Fogszabályozás Tanszékének beteganyagából származtak, a kutatást az egyetem Tudományos Kutatás Etikai Bizottsága a 117/21.11.2013. iktatószámmal jóváhagyta. Minden esetben a páciens írásbeli beleegyezését adta a tanulmányban való részvételhez, a felvételek ugyanazzal a röntgengéppel (Cranex D, Soredex, Finnország) készültek. A különböző vertikális arctí- pusok elkülönítése előzetes számítógépes távröntgenkiértékelésen (AudaxCeph szoftver) mért divergenciaszög (a maxilla és mandibula alapsíkja által bezárt szög) alapján történt. Alanyainkat 32,5\%-ban a normodivergens (divergenciaszög 23-28 között volt), 32,5\%-ban a hiperdivergens (divergenciaszög $28^{\circ}$ felett), illetve $35 \%$ ban a hipodivergens (divergenciaszög $23^{\circ}$ alatt) csoportba soroltuk.

Méréseinket csak a következő követelményeknek eleget tevő esetekben végeztük el:

1. Legyenek jelen a viszonyításhoz kiválasztott fogak (az első és második kis- és nagyőrlők), és jól láthatóak legyenek a gyökércsúcsaik!

2. Ne létezzen foghiányok okozta fogvándorlás, az oldalsó fogakon ne létezzen gyökérkezelés vagy periapicalis elváltozás!

3. Jól látható legyen a CM alsó fala, az FM első pereme, a mandibula bázisa, valamint az állkapocs felszálló ágának első és hátsó széle!

\section{Mérések elvégzése}

A méréseket az Image Pro Insight nevű program segítségével digitális, 1:1 kalibrált felvételeken végeztük, minden esetben a bal oldalon, 17 mérést minden röntgenen, ami 1360 mérést jelentett összesen. A mérések azonosságának érdekében minden röntgenen meghatározott érintőkre merőlegesen történtek a mérések (1. ábra).

\section{Az FM helyzetének vizsgálata}

Érintőt húztunk a felszálló ág hátsó szélére: az állkapocsszöglet legfelső és legkülső pontjából az ízületi fejecs nyakának alapjáig. Erre az érintőre merólegest húztunk az első széltől érintve az FM első szélének legfelső pontját, majd ebből a pontból újabb merólegest az érintőre. Az utóbbi meróleges adta az FM és hátsó szél közötti távolságot és ezt kivonva az első merőleges hosszából, megkaptuk az FM és első szél közti távolságot. Az állkapocsszöglettől való távolság mérésére az állkapocsszöglet legalsó pontját kötöttük össze az FM első szélének legfelső pontjával.

\section{A CM lefutásának vizsgálata}

Érintőt húztunk a mandibulatest alapjára: a mentum legalsó pontjától az állkapocsszöglet legalsó pontjáig. Erre az érintőre merőlegeseket húztunk a második kisőrlő és első nagyőrlő közötti, valamint az első és második nagyőrlő közötti interdentalis septumcsúcsból, az első és második nagyőrlő mesialis és distalis gyökércsúcsától. Azokból a pontokból, amelyekben ezek az érintők metszették a csatorna alsó falát, újabb merőlegeseket húztunk az érintőre, így megkaptuk a csatorna és állcsont alapja közti távolságokat, majd ezeket kivonva az először húzott merőlegesek hosszából, megkaptuk a csatorna 


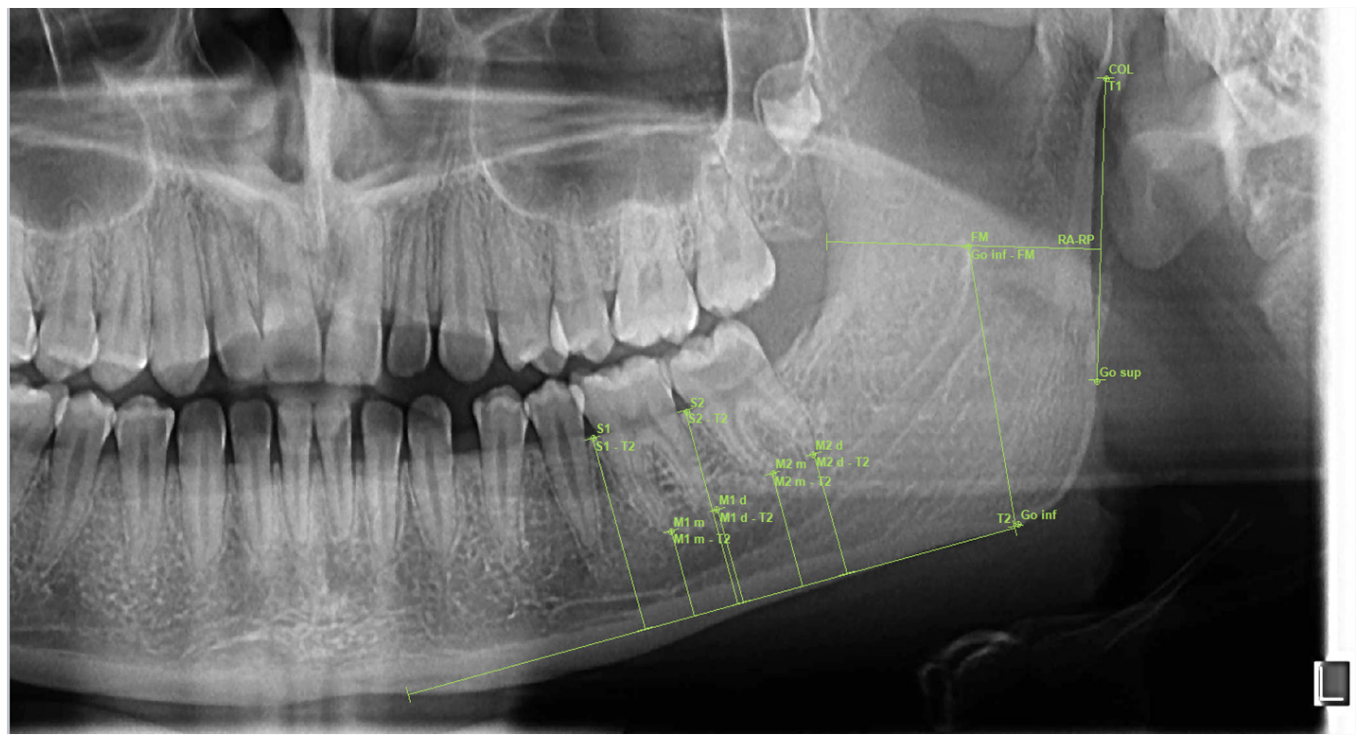

alsó fala és az interdentalis septumcsúcsok, valamint gyökércsúcsok közti távolságokat.

Az állkapocsszöglet és CM távolságának mérésére az állkapocsszöglet legalsó pontjából, vagyis az érintő utolsó pontjára merólegest húztunk a csatorna alsó falától. Ez után a csatorna lefutási meredekségének vizsgálata érdekében a csatorna alsó falának különböző pontjaiban szögeket mértünk. Ezek a pontok: az állkapocsszöglet legalsó pontja felett, az első és második molaris distalis gyökércsúcsai alatt, azokban a pontokban, ahol a merőlegesek metszették a csatorna alsó falát.

A mérésekben ejtett hiba meghatározására öt röntgenen újra megtörténtek a mérések egy hónap különbséggel.

1. táblázat | A statisztikai számítások eredményei

\begin{tabular}{|c|c|c|c|c|c|}
\hline \multirow[t]{2}{*}{ Vizsgált képlet } & \multirow[t]{2}{*}{ Mért távolság } & $\begin{array}{l}\text { Normo- és } \\
\text { hiperdivergens }\end{array}$ & $\begin{array}{l}\text { Normo- és } \\
\text { hipodivergens }\end{array}$ & $\begin{array}{l}\text { Hipo- és } \\
\text { hiperdivergens }\end{array}$ & \multirow{2}{*}{$\begin{array}{l}\text { Normo-, } \\
\text { hipo- és } \\
\text { hiperdivergens } \\
\text { ANOVA }\end{array}$} \\
\hline & & \multicolumn{3}{|c|}{$\mathrm{t}$-teszt } & \\
\hline \multirow[t]{3}{*}{ FM helyzete } & RP-FM & 0,6 & $0,018^{*}$ & $0,0017^{*}$ & $0,0054^{*}$ \\
\hline & RA-FM & 0,22 & 0,39 & 0,61 & 0,43 \\
\hline & Go inf-FM & 0,46 & 0,23 & $0,08^{*}$ & 0,177 \\
\hline \multirow{4}{*}{$\begin{array}{l}\text { A CM lefutása a gyökércsúcsokhoz és } \\
\text { interdentalis csontseptumokhoz viszonyítva }\end{array}$} & $\mathrm{Mlm}-\mathrm{CM}$ & 0,02 * & 0,51 & 0,13 & $0,09^{*}$ \\
\hline & Mld-CM & $0,04^{*}$ & 0,7 & 0,1 & 0,1 \\
\hline & SI-CM & 0,23 & 0,3 & 0,88 & 0,44 \\
\hline & S2-CM & 0,1 & 0,3 & 0,5 & 0,3 \\
\hline \multirow{7}{*}{$\begin{array}{l}\text { A CM lefutása a mandibula bázisának } \\
\text { érintójéhez, valamint állkapocsszöglethez } \\
\text { viszonyítva }\end{array}$} & $\mathrm{CM}-\mathrm{T} 2(\mathrm{~S} 1)$ & 0,1 & $0,008^{*}$ & 0,14 & 0,014 \\
\hline & $\mathrm{CM}-\mathrm{T} 2(\mathrm{Mlm})$ & 0,23 & $0,008^{*}$ & 0,1 & $0,02^{*}$ \\
\hline & $\mathrm{CM}-\mathrm{T} 2(\mathrm{Mld})$ & 0,5 & $0,03^{*}$ & 0,07 & 0,059 \\
\hline & CM-T2 (S2) & 0,8 & $0,03^{*}$ & 0,02 * & 0,02 * \\
\hline & $\mathrm{CM}-\mathrm{T} 2(\mathrm{M} 2 \mathrm{~m})$ & 0,3 & $0,04^{*}$ & $0,01^{*}$ & $0,04^{*}$ \\
\hline & $\mathrm{CM}-\mathrm{T} 2(\mathrm{M} 2 \mathrm{~d})$ & 0,6 & 0,1 & $0,008^{*}$ & $0,08^{*}$ \\
\hline & Go inf-CM & 0,1 & 0,3 & $0,008^{*}$ & 0,1 \\
\hline \multirow[t]{3}{*}{ A CM alsó falának lefutásán mért szögértékek } & Go inf & $0,04^{*}$ & $0,02 *$ & $0,01^{*}$ & $0,03^{*}$ \\
\hline & M2d & 0,4 & 0,2 & 0,7 & 0,53 \\
\hline & Mld & 0,4 & 0,8 & 0,5 & 0,99 \\
\hline
\end{tabular}

${ }^{*} \mathrm{p}<0,05$ - statisztikailag szignifikáns eltérés. 


\section{Mért értékek feldolgozásának módja}

A mérés során kapott értékeket a Microsoft Excel programba vezettük be, a mérések közti korrelációs érték meghatározása után rendszereztük a vizsgált paramétereket. Nemek szerinti, illetve korcsoport szerinti elkülönítésre nem került sor. A következő lépés a kiugró értékek kiszürése volt a Quick Outlier Calculator segítségével a Graphpad program keretén belül. A normalitás vizsgálatának elvégzése Shapiro Wilk-teszt segítségével történt. Ugyanez a teszt megadta az átlagértékeket és standard deviáció értékeit minden vizsgált méréscsoport esetén. Továbbá ANOVA-, majd páratlan t-teszt segítségével vizsgáltuk a csoportok közötti statisztikailag szignifikáns eltérések jelenlétét. A szignifikanciaszint 0,05 volt $(\mathrm{p}<0,05)$.

\section{Eredmények}

A mérésen belül ejtett hiba vizsgálatakor a kapott korrelációs együttható értéke minden mérésre vonatkozóan 0,85 fölött volt, ami kiválónak számít. A kiugró értékek kiszűrése során összesen öt mérés értéke bizonyult kiugró értéknek, amelyeket a tanulmány a továbbiakban nem vett figyelembe (1. táblázat).

\section{FM belyzete}

A felszálló ág hátsó széle és az FM közti távolság vizsgálatakor szignifikáns eltérés volt a három csoport között, a normo- és hipodivergens csoport, illetve a hiper- és hipodivergens csoport között. Mindkét esetben a hipodivergens arctípusnál volt ez a távolság nagyobb. Normodivergens és hiperdivergens típus között nem volt szignifikáns az eltérés.

A felszálló ág első széle és az FM közti távolságban az ANOVA-teszt alapján nem volt szignifikáns különbség a három csoport között, valamint a t-teszt sem talált szignifikáns eltérést a vizsgált csoportok páronként történő összehasonlítása esetén. Az FM és a mandibulaszöglet közötti távolságban nem volt szignifikáns eltérés a három vizsgált arctípus esetén (2. táblázat).

\section{A canalis mandibularis távolsága az interdentalis septumcsúcsoktól, valamint a gyökércsúcsoktól}

Az első kis- és első nagyőrlő közötti septumcsúcs és a CM alsó fala közti távolság vizsgálatakor nem találtunk szignifikáns eltérést a három arctípus között sem.

$\mathrm{Az}$ első nagyőrlő mesialis gyökércsúcsa és a CM alsó fala között a három arctípus között nem található szignifikáns különbség, viszont a hiperdivergens csoport szignifikánsan kisebb távolsággal rendelkezett, mint a normodivergens.
2. táblázat Az FM helyzete: átlagértékek, standard deviációk, minimummaximum értékek milliméterben kifejezve. RP-FM - felszálló ág hátsó szélére húzott érintő és foramen mandibulae közti távolság; RA-FM - felszálló ág első széle és foramen mandibulae közti távolság; Go inf-FM - állkapocsszöglet és foramen mandibulae közti távolság

\begin{tabular}{ll|l|l|l}
\hline & & $\begin{array}{l}\text { Normo- } \\
\text { divergens }\end{array}$ & Hiperdivergens & Hipodivergens \\
\hline RP-FM & Átlag \pm SD & $12,7 \pm 1,71$ & $12,42 \pm 1,13$ & $14,25 \pm 1,45$ \\
& Min.-Max. & $9,7-16,7$ & $10,4-18,0$ & $11,7-16,5$ \\
\hline RA-FM & Átlag \pm SD & $11,98 \pm 1,53$ & $10,91 \pm 2,31$ & $11,32 \pm 1,77$ \\
& Min.-Max. & $9,7-14,7$ & $7,1-15,5$ & $8,8-15,3$ \\
\hline Go & Átlag \pm SD & $29,48 \pm 2,84$ & $28,51 \pm 3,76$ & $30,88 \pm 3,11$ \\
inf-FM & Min.-Max. & $24,6-33,7$ & $23,6-37,6$ & $26,5-35,3$ \\
\hline
\end{tabular}

3. táblázat A CM lefutása a gyökércsúcsokhoz és interdentalis csontseptumokhoz viszonyítva - átlagértékek, standard deviáció, minimum-maximum értékek milliméterben kifejezve. Mlm-CM első molaris mesialis gyökércsúcsa és a $\mathrm{CM}$ alsó fala közti távolság; Mld-CM - első molaris distalis gyökércsúcsa és a CM alsó fala közti távolság; S1-CM - elsô praemolaris és első molaris közti septum csúcsa és a CM alsó fala közti távolság; S2-CM első és második molaris közti septum csúcsa és a CM alsó fala közti távolság

\begin{tabular}{ll|l|l|l}
\hline & & $\begin{array}{l}\text { Normo- } \\
\text { divergens }\end{array}$ & $\begin{array}{l}\text { Hiper- } \\
\text { divergens }\end{array}$ & $\begin{array}{l}\text { Hipo- } \\
\text { divergens }\end{array}$ \\
\hline Mlm-CM Átlag \pm SD & $6,02 \pm 2,13$ & $4,36 \pm 1,4$ & $5,47 \pm 2,18$ \\
& Min.-Max. & $2,6-9,4$ & $2,1-6,3$ & $2,3-8,5$ \\
\hline Mld-CM & Átlag \pm SD & $5,70 \pm 1,71$ & $2,03 \pm 1,36$ & $5,46 \pm 2$ \\
& Min.-Max. & $2,6-8,7$ & $2,1-7,8$ & $2,6-9,2$ \\
\hline S1-CM & Átlag \pm SD & $21,32 \pm 2,07$ & $20,92 \pm 2,21$ & $20,42 \pm 2,35$ \\
& Min.-Max. & $16,4-24$ & $15,6-25,7$ & $17,4-24,6$ \\
\hline \multirow{2}{*}{ 22-CM } & Átlag \pm SD & $19,37 \pm 1,40$ & $17,92 \pm 2,92$ & $18,56 \pm 2,3$ \\
& Min.-Max. & $14-22,1$ & $13,0-24,8$ & $12,6-21,6$ \\
\hline
\end{tabular}

Az első molaris distalis gyökércsúcsa és a CM távolsága a három csoport között nem mutatott szignifikáns eltérést, de hiperdivergens típusnál ez a távolság szignifikánsan kisebb volt, mint a normodivergens típusnál.

Az első molaris és második nagyőrlő közti interdentalis septum csúcsa és a CM közötti távolság nem változott szignifikánsan a három csoport között, és a csoportokat egymással hasonlítva sem volt szignifikáns a különbség (3. táblázat).

\section{A CM távolsága az állkapocs alapsikjától és az állkapocsszöglettöl}

Az első kis- és első nagyőrlő közötti septumcsúcs alatt a CM alsó fala és az állkapocs alapjára húzott érintő közötti távolság vizsgálatakor szignifikáns különbség volt a há- 
rom arctípus között, a hipodivergens arctípus esetén ez a távolság szignifikánsan nagyobb volt, mint a normodivergens arctípusnál.

Az első molaris mesialis gyökércsúcsa alatt a távolság a CM és az alapsík között szignifikáns változást mutatott a három csoport között, illetve hipodivergens arctípus esetén szignifikánsan nagyobb volt a távolság, mint a normodivergensnél.

Az első molaris distalis gyökere alatt ez a távolság a három csoport között nem volt szignifikáns, viszont a hipodivergens típusú egyéneknél szignifikánsan nagyobb volt a távolság, mint a normodivergens típusúaknál.

Az első és második nagyőrlő közötti csontseptum csúcsa alatt a CM-mandibula bázistávolság szignifikáns változást mutatott a három arctípus között. A hipodivergens szignifikánsan nagyobb távolsággal rendelkezett, mint a normo-, valamint a hiperdivergens csoport.

A második nagyőrlő mesialis gyökércsúcsa alatt a CMmandibula bázisérintő közti távolság szignifikáns eltérést mutatott a három csoport között, a hipodivergens arctípusú egyéneknél ez a távolság szignifikánsan nagyobb, mint a normo- és a hiperdivergens egyéneknél. A második nagyőrlő distalis gyökércsúcsa alatt ez a távolság a három csoport között nem változott szignifikánsan, a hipodivergens típusnál szignifikánsan nagyobb volt, mint a hiperdivergensnél.

$\mathrm{Az}$ állkapocsszöglet és a CM alsó fala közti távolság szignifikánsan változott a három arctípus között, a hipodivergens egyéneknél szignifikánsan nagyobb volt az értéke, mint a hiperdivergensnél, de nem volt szignifikáns különbség a másik két összehasonlítás között (4. táblázat).

\section{A CM meredeksége}

Az állkapocsszöglet legalsó pontja fölött mérve a CM alsó falának lefutási szöge szignifikáns eltérést mutat a három arctípus között, a hipodivergens szignifikánsan kisebb szögértéket mutatott, mint a normo-, illetve a hiperdivergens típus. Az első, illetve a második molaris distalis gyökércsúcsa alatti pontban nem volt szignifikáns különbség a CM alsó falának lefutási szögében sem a három csoport, sem a csoportokat páronként történő öszszehasonlításban (5. táblázat).

\section{Megbeszélés}

A felszálló ág hátsó széléhez húzott érintőtől az FM távolabb helyezkedett el azon egyéneknél, akik hipodivergens arctípussal rendelkeznek. Ez a távolság átlag 14,25 $\mathrm{mm}$ volt, míg a normo-, illetve hipodivergens arctípussal rendelkezóknél 12,7 mm, illetve 12,42 mm. Ez az információ hasznos lehet bármely olyan beavatkozás során, amely a felszálló ág hátsó széle, illetve a nyílás közti területet érinti. A felszálló ág első széléhez viszonyított távolsága a nyílásnak nem változott szignifikánsan a három csoport között. Ez arra enged következtetni, hogy a hi-
4. táblázat $\mid$ A CM lefutása a mandibula bázisának érintőjéhez, valamint állkapocsszöglethez viszonyítva milliméterben kifejezve. CM-T2 (S1) - az első praemolaris és első molaris közti interdentalis csontseptum csúcsa alatt a CM alsó fala és mandibulabázis érintője közti távolság; CM-T2 (Mlm) - első molaris mesialis gyökércsúcsa alatt a $\mathrm{CM}$ alsó fala és bázisérintője közti távolság; CM-T2 (Mld) - első molaris distalis gyökércsúcsa alatt a CM alsó fala és bázisérintője közti távolság; CM-T2 (S2) - az első molaris és második molaris közti interdentalis csontseptum csúcsa alatt a CM alsó fala és mandibula bázisérintője közti távolság; CM-T2 (M2m) - második molaris mesialis gyökércsúcsa alatt a CM alsó fala és bázis érintője közti távolság; CM-T2 (M2d) - második molaris distalis gyökércsúcsa alatt a CM alsó fala és bázisérintője közti távolság; Go inf-CM - állkapocsszöglet legalsó pontja és a csatorna alsó fala közti távolság

\begin{tabular}{ll|l|l|l}
\hline & & $\begin{array}{l}\text { Normo- } \\
\text { divergens }\end{array}$ & $\begin{array}{l}\text { Hipo- } \\
\text { divergens }\end{array}$ & $\begin{array}{l}\text { Hiper- } \\
\text { divergens }\end{array}$ \\
\hline CM-T2 & Átlag \pm SD & $0,98 \pm 1,44$ & $2,58 \pm 1,47$ & $1,83 \pm 1,08$ \\
\cline { 2 - 5 }$($ S1 $)$ & Min.-Max. & $-1,6-3,6$ & $0,6-5,4$ & $0,9-4,3$ \\
\hline CM-T2 & Átlag \pm SD & $1,05 \pm 1,35$ & $2,62 \pm 1,5$ & $1,69 \pm 1,33$ \\
\cline { 2 - 5 }$($ M1m) & Min.-Max. & $-1-3,5$ & $0,5-5,5$ & $-0,4-4,5$ \\
\hline CM-T2 & Átlag \pm SD & $1,72 \pm 1,53$ & $3,03 \pm 1,44$ & $2,03 \pm 1,36$ \\
\cline { 2 - 5 }$($ M1d) & Min.-Max. & $-0,1-4,2$ & $0,7-5,7$ & $0,5-5,1$ \\
\hline CM-T2 & Átlag \pm SD & $1,80 \pm 1,44$ & $3,06 \pm 1,43$ & $1,88 \pm 0,93$ \\
\cline { 2 - 5 }$($ S2) & Min.-Max. & $-0,3-4,2$ & $0,8-5,7$ & $0,9-5,6$ \\
\hline CM-T2 & Átlag \pm SD & $3,40 \pm 2,02$ & $4,8 \pm 1,43$ & $3,36 \pm 1,52$ \\
\cline { 2 - 5 }$($ M2m) & Min.-Max. & $1-7,5$ & $2,4-6,6$ & $1,2-6,4$ \\
\hline CM-T2 & Átlag \pm SD & $4,94 \pm 2,56$ & $6,1 \pm 1,16$ & $4,51 \pm 1,68$ \\
\cline { 2 - 5 }$($ M2d) & Min.-Max. & $1,2-10$ & $3,1-8,1$ & $2,1-7$ \\
\hline Go inf- & Átlag \pm SD & $15,40 \pm 3,71$ & $16,62 \pm 3,08$ & $13,47 \pm 2,33$ \\
\cline { 2 - 5 } CM & Min.-Max. & $9,7-21,8$ & $10,5-21,1$ & $10,4-22,9$ \\
\hline
\end{tabular}

5. táblázat

A CM alsó falának lefutásán mért szögértékek (átlagérték, stan dard deviáció, minimum és maximum mért értékek). Go inf - a CM alsó falának lefutási szöge az állkapocsszöglet legalsó pontja fölött mérve; M2d - a CM alsó falának lefutási szöge a második nagyőrlő distalis gyökércsúcsa alatt; $\mathrm{Mld}$ - a CM alsó falának lefutási szöge az első nagyőrlő distalis gyökércsúcsa alatt

\begin{tabular}{|c|c|c|c|c|}
\hline & & $\begin{array}{l}\text { Normo- } \\
\text { divergens }\end{array}$ & $\begin{array}{l}\text { Hipo- } \\
\text { divergens }\end{array}$ & $\begin{array}{l}\text { Hiper- } \\
\text { divergens }\end{array}$ \\
\hline \multirow[t]{2}{*}{ Go inf } & Átlag \pm SD & $\begin{array}{l}177,64 \\
\pm 5,19^{\circ}\end{array}$ & $\begin{array}{l}173,8 \\
\pm 3,24^{\circ}\end{array}$ & $\begin{array}{l}177,82 \\
\pm 4,7^{\circ}\end{array}$ \\
\hline & Min.-Max. & $\begin{array}{l}167,3- \\
188,3^{\circ}\end{array}$ & $\begin{array}{l}168,28- \\
178,87^{\circ}\end{array}$ & $\begin{array}{l}169,7- \\
184,6^{\circ}\end{array}$ \\
\hline \multirow[t]{2}{*}{$\mathrm{M} 2 \mathrm{~d}$} & Átlag \pm SD & $\begin{array}{l}173,67 \\
\pm 3,12^{\circ}\end{array}$ & $\begin{array}{l}170,55 \\
\pm 8,44^{\circ}\end{array}$ & $\begin{array}{l}171,72 \\
\pm 8,69^{\circ}\end{array}$ \\
\hline & Min.-Max. & $\begin{array}{l}168,2- \\
179,9^{\circ}\end{array}$ & $\begin{array}{l}151,79- \\
185,8^{\circ}\end{array}$ & $\begin{array}{l}151,5- \\
184,6^{\circ}\end{array}$ \\
\hline \multirow[t]{2}{*}{ Mld } & Átlag \pm SD & $\begin{array}{l}173,87 \\
\pm 4,79^{\circ}\end{array}$ & $\begin{array}{l}174,49 \\
\pm 4,57^{\circ}\end{array}$ & $\begin{array}{l}172,34 \\
\pm 4,79^{\circ}\end{array}$ \\
\hline & Min.-Max. & $\begin{array}{l}163,2- \\
179,8^{\circ}\end{array}$ & $\begin{array}{l}155,46- \\
180,5^{\circ}\end{array}$ & $\begin{array}{l}167- \\
181,7^{\circ}\end{array}$ \\
\hline
\end{tabular}

podivergens arctípus esetén nem a nyílás előrébb való elhelyezkedéséról van szó a többi arctípushoz képest, hanem az állkapocs felszálló ága a nyílás mögötti területen szélesebb, mint a másik két csoportnál. Hasonló ta- 
nulmányok valódi progéniában háromdimenziós imagisztikai eljárással mérték ugyanezeket a távolságokat [10], és az ezekben az esetekben tapasztalt túlfejlett csontos alap magyarázza az eltéréseket. A mieinkkel megegyező eredményeket is találtak, a különbség csak az FM területén választott referenciapontban rejlett [12].

Az FM helyzetének tanulmányozása során azt találták, hogy a nyílás helyzete korcsoportonként változik, és gyerekkorban a felszálló ág középső harmadának hátsó részén, míg felnőttkorban az elülső részén található [13]. A mieinkhez hasonlóan számbeli adatokkal indokolták azt, hogy a nyílás helyzetét befolyásolja a felszálló ág anteroposterior méretbeli változása, vagyis a csont szélességbeli növekedésének változása befolyásolja az FM helyzetét [14].

A CM lefutását vizsgálva a csatorna alsó fala és az interdentalis csontseptumcsúcsok közti távolság nem mutatott szignifikáns különbséget a három arctípus között. Összességében elmondható, hogy mindhárom arctípusnál megfigyelhető volt, hogy a csatorna a második praemolaris és első molaris közti csontseptum csúcsához közelebb helyezkedik el, mint az első molaris és második molaris köztihez, ezt egyéb tanulmányok is igazolták [15]. Az első molaris gyökércsúcsaihoz viszonyítva már található szignifikáns eltérés a csoportok között. A mesialis és distalis gyökércsúcs esetén is ugyanaz volt megfigyelhető: a hiperdivergens arctípussal rendelkező egyéneknél közelebb helyezkedett el a csatorna a gyökércsúcsokhoz, mint a normodivergens arctípusú egyéneknél.

A CM alsó fala és az állkapocs bázisának érintője közti távolság nem változott szignifikánsan a hiperdivergens és normodivergens csoport között, tehát nem lehet a csatorna magasabb helyzetérôl beszélni. Hiperdivergens egyéneknél ez a távolság átlagosan a mesialis gyökér területén $4,36 \mathrm{~mm}$ volt, normodivergens arctípusú egyéneknél 6,02 mm, míg a distalis gyökércsúcsnak megfelelően a távolság hiperdivergens arctípusnál átlag 4,23 $\mathrm{mm}$, normodivergensnél $5,7 \mathrm{~mm}$ volt. A hiper- és hipodivergens, valamint hipo- és normodivergens csoportot összehasonlítva nem volt szignifikáns különbség ezekben a mérésekben. Ez az információ több beavatkozás során is hasznos lehet, mint például a gyökércsúcsok csonkolása vagy/és endodontiai kezelése, mert magas alsó archarmad esetén számítani lehet rá, hogy a csatorna közelebb található a gyökércsúcsokhoz. Hasonló átlagértékeket találtak az első nagyőrlő gyökércsúcsainak megfelelően (mesialis gyökér 5,56 mm, distalis gyökér 5,17 $\mathrm{mm}$ ) anélkül, hogy különböző arctípusokat vizsgáltak volna [16], eredményeinktől való kisebb eltéréseket valószínúleg az arctípusoktól való elvonatkoztatás magyarázza. (Az általunk mért átlagtávolságok mesialis gyökércsúcs alatt normodivergens típusnál 6,02 $\mathrm{mm}$, hiperdivergens arctípus esetén 4,36 mm, distalis gyökércsúcs alatt normodivergens $5,7 \mathrm{~mm}$, hipodivergens 5,62 $\mathrm{mm}$, hiperdivergens $4,23 \mathrm{~mm}$.)
A CM helyzetében az állkapocs alapjára húzott érintőhöz viszonyítva ugyancsak szignifikáns eltéréseket találtunk a vertikális arctípusok függvényében. Szignifikánsan nagyobb távolság volt a csatorna alsó fala és az állkapocs bázisára húzott érintő között hipodivergens arctípus esetén, mint normodivergensnél (első praemolaris és első molaris közti septumcsúcs alatt mérve 2,58 $\mathrm{mm}$, illetve $1,8 \mathrm{~mm}$, az első molaris mesialis gyökércsúcs alatt mérve 2,62 mm, illetve $1,05 \mathrm{~mm}$, az első molaris distalis gyökér csúcsa alatt mérve $4,8 \mathrm{~mm}$, illetve 3,4 mm, az első-második molaris közti septumcsúcs alatt mérve $3,06 \mathrm{~mm}$, illetve $1,8 \mathrm{~mm}$, a második nagyőrlő mesialis gyökércsúcsa alatt mérve $4,8 \mathrm{~mm}$, illetve $3,4 \mathrm{~mm}$ ). Tehát minden esetben a hipodivergens típusoknál volt nagyobb távolság a csatorna alsó fala és az állkapocs érintője között. A CM lefutása során a legelső vizsgált ponttól hátrafele egyre inkább távolodott az állkapocs alapjára húzott érintőtől.

A CM alsó falának lefutási szögeit vizsgálva egyetlen pontban volt szignifikáns különbség a három arctípus között. Az állkapocsszöglet legalsó pontjából merőlegest húzva a csatorna alsó falára és ahol ez a meróleges metszette a csatornát, abban a pontban mértük a szögértéket. Ebben a pontban a normális alsó archarmaddal (átlag $\left.177,64^{\circ}\right)$ és a magasabb alsó archarmaddal $\left(177,82^{\circ}\right)$ rendelkező egyéneknél nyitottabb a csatorna lefutása, mint az alacsonyabb alsó archarmadú $\left(173,88^{\circ}\right)$ egyéneknél.

Több tanulmány is foglalkozott már az állkapocs morfológiai változásaival a különböző vertikális növekedési irányok szerint. Ezek a változások fontosak az orthodontiai kezelési terv felállításakor [7, 9]. CBCT-ken végzett tanulmányok arra derítettek fényt, hogy a condylus morfológiáját és helyzetét befolyásolja az, hogy egy egyén hipo- vagy hiperdivergens arctípussal rendelkezik, illetve hiperdivergens arctípus esetén a buccalis corticalis rétegnél kisebb csontsưrüséget találtak, mint hipo-, illetve normodivergens arctípus esetén [8]. Megállapították, hogy a vertikális arctípusok függvényében változások vannak a symphysis, illetve a felszálló ág méreteiben és hogy a csatorna lefutásában észlelt különbségek az eltérő csontos növekedési iránynak tudhatók be.

Tanulmányunkban a CM lefutásának vizsgálatára a panorámaröntgent választottuk, mivel az állcsontok kivetített ábrázolására képes és nagyjából helyes mérések elvégzésére alkalmas az állkapocs hátsó részén $[10,16]$. Hátránya a kétdimenziós képalkotás, emiatt a CM lefutásbeli változásait nem tudtuk bucolabialis irányban vizsgálni. Előnyös lenne egy hasonló tanulmány elvégzése háromdimenziós képalkotó eljárást használva, ezáltal vizsgálni lehetne az ilyen irányú változásokat is. Tanulmányunkban nem vizsgáltuk a bölcsességfog gyökércsúcsa és a csatorna közti távolságot, mivel az általunk vizsgált egyéneknél a gyökérfejlődés még folyamatban volt és nem tudtunk biztos referenciapontokat meghatározni. 


\section{Következtetések}

A CM lefutása, valamint az FM helyzete szignifikáns eltéréseket mutatott panoráma-röntgenfelvételeken vizsgálva a különböző vertikális arctípusok függvényében. Ez az információ több fogászati beavatkozás kapcsán is hasznos lehet.

1. Az FM hipodivergens egyéneknél távolabb helyezkedett el a felszálló ág hátsó szélétől, mint a többi arctípus esetén. A felszálló ág első széléhez, valamint az állkapocsszöglethez viszonyítva, helyzetét tekintve nem volt szignifikáns eltérés a különböző vertikális arctípusok között.

2. Hiperdivergens alanyok esetén a CM alsó fala közelebb helyezkedett el az első nagyőrlő mesialis és distalis gyökércsúcsához, mint normodivergens arctípus esetén.

3. Hipodivergens egyének esetén a CM alsó fala távolabb helyezkedett el az állkapocs alapjához húzott érintőtől: a második praemolaris utáni interdentalis csontseptum csúcsa és az első molaris distalis gyökere közti részen a szignifikáns különbség a normodivergens csoportban volt megfigyelhető, majd a második molaris mesialis gyökércsúcsáig a szignifikáns különbség mind a két másik vertikális arctípusnál jelen volt, majd az ennél hátrábbi részen már csak a hiperdivergens egyénekre volt jellemző.

4. A különböző vertikális arctípusok között tapasztalt eltérő CM-lefutás tulajdonképpen a csont méretbeli növekedésének tulajdonítható. Úgy tűnik, hogy hipodivergens egyéneknél a csont a csatorna alatt kifejezettebb vertikális növekedést, az FM mögötti részen pedig nagyobb szélességbeli növekedést mutat, míg hiperdivergens egyéneknél a csatorna felett kisebb magasságbeli növekedés volt megfigyelhető az elsó molaris gyökércsúcsai alatt.

Anyagi támogatás: A közlemény megírása, illetve a hozzá tartozó kutatómunka anyagi támogatásban nem részesült.

Szerzôi munkamegosztás: M. I. K.: A tanulmányba bevont esetek szelekciója, anyag és módszer - távröntgenek és mérések kiértékelése, a közlemény végleges szerkesztése. C.B. : Image Pro Insight program felhasználása, az eredmények végső kiértékelése, a közlemény szerkesztése. K. B.: Mérések elvégzése az Image Pro Insight program segítségével, adatok összesítése, szakirodalom tanulmányozása. K. M. B.: Adatok statisztikai feldolgozása és kiértékelése, a közlemény szerkesztése. A cikk végleges változatát mindhárom szerző elolvasta és jóváhagyta.

Érdekeltségek: A szerzőknek nincsenek érdekeltségeik.

\section{Irodalom}

[1] Thangavelu K, Kannan R, Kumar NS, et al. Significance of localization of mandibular foramen in an inferior alveolar nerve block. J Nat Sci Biol Med. 2012; 3: 156-160.

[2] Shavit I, Juodzbalys G. Inferior alveolar nerve injuries following implant placement - Importance of early diagnosis and treatment: a systematic review. J Oral Maxillofac Res. 2014; 5: e2.

[3] Iannetti G, Fadda TM, Riccardi E, et al. Our experience in complications of orthognathic surgery: a retrospective study on 3236 patients. Eur Rev Med Pharmacol Sci. 2013; 17: 379-384.

[4] Szalma J, Lempel E, Jeges S, et al. The prognostic value of panoramic radiography of inferior alveolar nerve damage after mandibular third molar removal. Retrospective study of 400 cases. Oral Surg Oral Med Oral Pathol Oral Radiol Endod. 2010; 109: 294-302.

[5] Bhardwaj D, Kumar JS, Mohan V. Radiographic evaluation of mandible to predict the gender and age. J Clin Diagn Res. 2014; 8: ZC66-ZC69.

[6] Ngeow WC, Dionysius DD, Ishak H, et al. Effect of ageing towards location and visibility of mental foramen on panoramic radiographs. Singapore Dent J. 2010; 31: 15-19.

[7] Mangla R, Singh N, Dua V, et al. Evaluation of mandibular morphology in different facial types. Contemp Clin Dent. 2011; 2: 200-206.

[8] Ozdemir F, Tozlu M, Germec Cakan D. Quantitative evaluation of alveolar cortical bone density in adults with different vertical facial types using cone-beam computed tomography. Korean J Orthod. 2014; 44: 36-43.

[9] Park IY, Kim JH, Park YH. Three-dimensional cone-beam computed tomography based comparison of condylar position and morphology according to the vertical skeletal pattern. Korean J Orthod. 2015; 45: 66-73.

[10] Hoseini Zarch SH, Bagherpour A, Javadian Langaroodi A, et al. Evaluation of the accuracy of panoramic radiography in linear measurements of the jaws. Iran J Radiol. 2011; 8: 97-102.

[11] Bogdán S, Pataky L, Barabás J, et al. Atypical courses of the mandibular canal: Comparative examination of dry mandibles and x-rays. J Craniofac Surg. 2006; 17: 487-491.

[12] Kang SH, Kim YH, Won YJ, et al. Novel three-dimensional position analysis of the mandibular foramen in patients with skeletal class III mandibular prognathism. Imaging Sci Dent. 2016; 46: $77-85$.

[13] Ashkenazi M, Taubman L, Gavish A. Age-associated changes of the mandibular foramen position in anteroposterior dimension and of the mandibular angle in dry human mandibles. Anat Rec. 2011; 294: 1319-1325.

[14] Anbiaee N, Eslami F, Bagherpour A. Relationship of the gonial angle and inferior alveolar canal course using cone beam computed tomography. J Dent. (Tehran) 2015; 12: 756-763.

[15] Afkhami F, Haraji A, Boostani HR. Radiographic localization of the mental foramen and mandibular canal. J Dent. (Tehran) 2013; 10: 436-442.

[16] Peker I, Alkurt MT, Michcioglu T. The use of 3 different imaging methods for the localization of the mandibular canal in dental implant planning. Int J Oral Maxillofac Implants. 2008; 23: 463-470.

(Cristina Bica dr.,

Gh. Marinescu utca 38, 540139 Marosvásárbely, Románia e-mail: cristina.iona.bica@gmail.com) 